In addition to his work on Mexico, Scott wrote on the politics of Argentina and Latin America generally, focusing on such topics as constitutional development, foreign policy, nation building, and student activism.

He travelled frequently in Mexico and, in 1982, was a participantobserver of the transfer of power from President José Lopez Portillo to President-elect Miquel de la Madrid Hurtado.

Scott is survived by two brothers: Jules of Naperville, Illinois, and Richard (a twin) of Chicago.

Samuel Gove University of Illinois, Urbana-Champaign

\section{Amry Vandenbosch}

Amry Vandenbosch, Founding Director of the Patterson School of International Commerce and Diplomacy and long-time chair and professor of political science at the University of Kentucky, died on Sunday, October 21, 1990. "Dr. Van" attended Calvin College not far from his hometown for his freshman and sophomore years, and then served as an enlisted man in the U.S. Army in Europe during World War I. Because he happened to be relatively fluent in French, he was transferred from his machine gun company and given a special assignment as a translator in liaison work between senior American and French generals. It was his first taste of international diplomacy - a subject and an activity that would occupy the rest of his professional life in one form or another.

After the Armistice, Vandenbosch returned home to Michigan but chose to resume his studies at the University of Chicago, where he received his undergraduate degree in 1920. Continuing directly into graduate studies, he earned his Ph.D. in 1926. Even today, the University of Chicago's department of political science during that 1920 s period is still regarded as perhaps the greatest group of scholars in this discipline ever assembled on one campus, shaping the field for decades to come. Van earned his doctoral degree under those "giants" - people such as Beard and Lasswell. His own work looked at the broad themes of international law, politics and organizations, but also on the more specialized subject of the Dutch overseas empire and its impact on those areas where the Dutch colonial impact was particularly heavy.

Vandenbosch did a little bit of high school teaching and also undertook a two-year teaching apprenticeship (1924-26) as a pre-doctoral instructor at Iowa State before immediately accepting a junior position as a political science faculty member at the University of Kentucky when his Ph.D. was completed in 1926. Aside from an occasional year as a visiting professor at distinguished institutions elsewhere, and not counting a brief period on the Centre College faculty after retiring at Kentucky, Dr. Van spent his entire academic career on the UK campusincluding 25 years (1933-58) as head of the department of political science and then six years (1959-65) at the first Director of the Patterson School. He received every honor that the University of Kentucky could bestow on a faculty member, including an honorary doctorate. He also received many other forms of professional recognition-for example, he was one of only two people to have served as president for both the Southern and the Midwestern Political Science Associations. He was clearly a prominent figure and strong influence in introducing and expanding international studies in these two major regions of the United States.

Although his age and his World

War I service would have gained him an exemption from service during World War II, Dr. Van took a leave of absence from UK in order to make his own contribution to the great effort-first, a year with the OSS (1941-42) in which his knowledge of the Dutch islands in the Southwest Pacific was used to develop a native network of observers to monitor the movement of Japanese ships; and then three years (1942-45) of diplomatic work with the U.S. Department of State. The pinnacle of his service in diplomacy was membership on the famous U.S. delegation to the San Francisco Conference in 1944-45 where the United Nations Charter was drafted and approved.
He was a friend and mentor to generations of students, many of whom went on to achieve distinguished careers of their own. He was equally well regarded by-and a benevolent influence on-numerous colleagues and thousands of others who knew him at one time or another over his long and lively life. A representative of the "old school" in believing that a professor had a duty to profess, Dr. Van was never without well-peppered and sometimes well-salted views on a wide range of public issues both domestic and international. Small in stature but large of heart, he could quickly smile during and after loud exchanges of views, often proposing a beer and a game of pool as the denouement for a vociferous shouting match.

$\mathrm{He}$ is survived by his widow and frequent scholarly collaborator, the former Mary Belle Wilcox, whom he married on March 22, 1926. Their two children are Robert, a distinguished professor of nuclear physics at the University of Washington, and Margaret Anne, who has held academic affiliations at Florida State University and elsewhere. All who knew Amry will miss him.

Contributions in memory of Amry Vandenbosch may be sent to: Amry Vandenbosch Memorial Fund, Patterson School of International Commerce and Diplomacy, 455 Patterson Office Tower, University of Kentucky, Lexington, KY 40506.

\section{Vincent Davis \\ Patterson School}

W. E. Lyons

University of Kentucky

\section{George V. Wolfe}

George V. Wolfe, professor emeritus at The College of Idaho, passed away on December 15, 1990 at his home in Caldwell, Idaho. He was 86 years old.

George Wolfe was born September 24, 1904, in Vienna, Austria, where he spent his childhood and later enrolled in the Doeblinger Gymnasium. He was admitted to the University of Vienna in 1922. At that time he wished to teach history and, since history teachers had to undertake other subjects, he majored in history, geography, and philosophy 
(which was required of everyone completing the Ph.D.). He completed his Ph.D. in 1928. Two years later he passed the state and university examinations and earned a J.D. at the University of Vienna. He served the required six years of apprenticeship in his father's law firm, was admitted to the Bar, and joined his father as an attorney.

When the Nazis occupied Austria in 1938, George Wolfe, like other Jewish attorneys who had not been licensed before World War I, was forbidden from the practice of law. In 1939, he and his wife Alice, a Ph.D. in Art History from the University of Vienna, escaped first to England and then to the United States. From February 1940 to September 1946, they were associated with Yale University where George was a Cowles Fellow. As he said, "I Americanized myself by taking all the courses, and passing with distinction all qualifying examinations required for candidates for the Ph.D. in political science at Yale."

In the fall of 1946, George Wolfe came to The College of Idaho in Caldwell, Idaho, where he established and developed the political science curriculum and a department that would make significant contributions to the liberal arts tradition. During the 24 years that he taught at
The College, $82 \%$ of the political science majors went on to law and graduate schools. In his capacity as pre-law adviser and as a representative of the Rhodes and Marshall Scholarship trusts, he encouraged students to compete for scholarships of national renown. Among the many scholarships awarded to students during his tenure were four Rhodes, two Marshall, three Harvard Law School, and ten University of Chicago Law School scholarships. After retirement in 1970, George Wolfe taught briefly at Millsaps College and Johnson State College before returning to Idaho where he continued to advise students who aspired to the legal professions. He was particularly encouraging and helpful to Black, Hispanic, and Japanese-American students.

George Wolfe was a sophisticated, thoughtful, and ardent teacher to a generation of College of Idaho students. As a scholar, his articles and book reviews appeared in the American Journal of International Law and the Western Political Quarterly. He was a consistent participant in professional organizations, presenting papers and chairing panels at meetings of the Western and Pacific Northwest Political Science Associations. His presidential address in April 1966 to the Pacific Northwest
Political Science Association, "Queries We Brush Aside," challenged political scientists to understand the limits of the scientific methodology when dealing with "human purposes and purposeful action," and to inquire into the meaning and application of "ultimate values." For George Wolfe, political science-particularly undergraduate political science-was not an academic discipline reduced just to causal explanations but one also obligated to revive the age-old valueoriented questions regarding "freedom," "equality," and, particularly, "justice." Political knowledge demanded empathy and imagination if it was to remain meaningful to the student of law and eventual public service.

George Wolfe will be greatly missed by faculty, friends, fellow political scientists in the Pacific Northwest, and many former students of The College of Idaho. $\mathrm{He}$ very rarely quoted scripture, but when he did, it usually was Ecclesiastes- "man's wisdom makes his face shine, and the hardness of his countenance is changed."

Orville G. Cope The College of Idaho

Wallace J. Lonergan

The College of Idaho 